\title{
WOMEN EMPOWERMENT THROUGH SELF-HELP GROUPS: A CASE STUDY IN HOOGLY DISTRICT OF WEST BENGAL, INDIA
}

\author{
SOMA SAHA \\ Assistant Professor, Department of Economics, Netaji Nagar College for Women, Kolkata, West Bengal, India
}

\section{ABSTRACT}

Women Empowerment refers to the process wherein women have the ability to take control over the choices of their life in an effort to promote their well-being. This paper-based on empirical research from the field survey in Pandua and Dhaniakhali blocks of Hooghly district of West Bengal, India-analyses the role of Self-Help Groups (SHGs) in enhancing the socioeconomic status of its members and its effect on the empowerment of women. A total of 300 households in the two blocks of Pandua and Dhaniakhali were surveyed. Both statistical and econometric techniques were used. Binary Probit regression model was used in order to examine the determinants of Women Empowerment. The study revealed that Self Help Group has helped to create a positive impact on the socio-economic livelihood of its members in the study area. Further, there has been marked improvement in several empowerment indices like social status, decision making ability and relative freedom from domination.

KEYWORDS: Self Help Groups, Rural Poor, Women Empowerment, Socio-Economic Livelihood

Received: Sep 15, 2020; Accepted: Oct 06, 2020; Published: Nov 11, 2020; Paper Id.: IJECRDEC20206

\section{INTRODUCTION}

Women are always an essential constituent of every economy, as they have an important role in economic development of the country. There is need for women to have greater economic participation. However, there is gender discrimination against women in health, education, economic independence, decision making, etc. As per the Global Gender Gap Report, 2018 of World Economic Forum (WEF), India is ranked 108 out of 148 countries. This report is primarily based on creation of a Global Gender Gap Index that analyses the gap between men and women in theirareas of economic participation, education, health and political involvement.

Women's empowerment is all about taking control over the various challenges being faced by them through their independent decisions, for overall betterment of their life and environment. Women's empowerment can also mean freedom in the society from discrimination in the areas of gender, caste, economy and politics. It also involves defining and working upon one's goals in life in order to become totally self-reliant. Empowerment ensures ability to exercise choice with respect to access of resources, process of decision making and achievements (Kabeer 1999). Women Empowerment is possible only through equal opportunities in economic, social and political spheres of their lives. In India, women's participation in the work force, the quality of work allotted to them and their contribution to the GDP has been poor. For the overall economic development of our country, it is very important that women gain a financial identity and have access to all the financial services and avail all the benefits offered by the government. However, in a country like India, due to lack of finance, education and enterprise it is quite difficult to involve rural poor women in activities for the society and economy. In order to 
mobilise and empower the rural women the concept of Self-Help Groups emerged.

Self-Help Groups (SHGs) are informal groups of people, usually 10-15 rural women with the same socioeconomic background who try to address their common problems and find ways to improve their living conditions. It involves self-employment for their economic development. The Self-Help Groups are also fully engaged in building up the capacity, technology and infrastructure for their members. They also play an important role in arrangingformal credit and help in marketing of theirproducts. The Self-Help Group's primary focus is to enhance the financial security of its members through economic empowerment and also improve their common interest areas of leadership, motivation and training. Several literatures have dealt on the topic of women empowerment through Self-Help Groups. Empirical study on participation of women in SHGs in Bangladesh has shown increased decision-making ability of their members both in household and society. It has also increased the bargaining power of the women in the areas of girl child education and marriage (Hashemi et al., 1996). Due to the diversity of women within the SHGs, their interactions in the group affairs can often lead to gain in their dynamic skills (Mbugua-Muruthi, 1997). A systematic review with the primary objective of examining the impact of Self-Help Groups on women's empowerment in countries having low and middle income, incorporating evidence from quantitative and qualitative studies, shows that there is a positive impact on the economic, social and political empowerment of its members in the study area (Campbell Collaboration, 2015).

A qualitative research on the role of SHGs in women empowerment in the rural Pondicherry, India reveals increased participation of the members in decision making in the household, greater respect in family, improved savings, involvement in small family spending and greater independence and confidence (Sahu \& Singh, 2012).Based on a survey of 888 women from 74 randomly selected blocks in Punjab, India with the primary objective to explore their income generating activities in the SHGs, Randhawa and Mann (2005), observed that joining the SHG has led to their increase in mobility, financial situation, decision making and confidence level.A survey of 120 women in Rajkot district of Gujarat, India engaged in SHGs, have shown that there has been increase in the knowledge gained and greater awareness on the various health issues of women andimprovedfinancial security during any health emergencies (Manvar, et al., 2019). A survey conducted in six municipalities in West Bengal, India on SHGs revealed reduced tolerance of domestic violence and enhanced status of members within the household (Husain, et al., 2010). An empirical study on women empowerment in Nadia district of West Bengal, India reveals an increase in the various indices in the family involving personal autonomy, decision making ability, domestic economic consultation and political autonomyas well as aggregate empowerment of all the members on joining Self-Help Groups (Garai, et al., 2012).

Self Help Groups (SHGs) have played an important role in changing the economic conditions of the rural poor women. Self-Help Groups have also had a major influence on the economic empowerment of their members. With this background and based on our primary data, this paper attempts to explore the role of Self-Help groups on economic empowerment of women in the study area.

The objectives of thisempirical research work are as follows:

- To examine the role of Self-Help Groups in developing socio-economic status of rural women

- To investigate empirically the effect of women's participation in Self Help Group on economic empowerment of women

\section{DATA AND METHODOLOGY}


This study is based on primary data collected from field survey on Self-Help-Groups in Hooghly district of West Bengal, India in 2017-2018. The field survey was undertaken in 6 villages of Pandua block viz.,Boichigram, Berala, Itachuna Khanyan, Pandua, Ponchgora Toregram, Haraldaspur and 4 villages of Dhaniakhali block viz.,Belmuri, Bhandarhati, Dashghara and Mandari. Total 300 households were surveyed. Based on the criteria that a Self-Help Group should have completed at least one year, 40 SHGs were selected for the sample in Pandua block and 20 SHGs from Dhaniakhali block. For the interview, we have selected five individual members from each sample group. The individuals selected for the interview were varied in terms of their age group, marital status, occupation held and the economic status. We have made a comparison between the level of empowerment of its members before and after joining the Self-Help Group in order to examine the extent of improvement after in the Self-Help Group programme was initiated. For this study, we have also examined and used secondary data that was available in different journals, books, related documents, newspapers and have extensively collected data from the records of National Rural Livelihood Mission (NRLM) constituted by the Ministry of Rural Development, Government of India.

A tabular method has been used in this study in order to quantify the social and economic impact of SHG activities on the rural women in the surveyed area. To examine the impact of women's participation in SHG on women empowerment, we have planned to estimate a binary probit model.

\section{Econometric Model}

We have proposed the following Model to examine the impact of SHG membership status on women empowerment of the rural women in our study area:

Women Empowerment $=f$ (Age, Family size, Female Percentage, Caste, Education, Land holding, Duration of SHG membership, Annual Earning, Training, random disturbance term)

A Binary Probit regression model has been used in this study in order to examine the determinants of Women Empowerment.

Our specified model is:

$$
\begin{aligned}
& \text { WOMENEMP }=\alpha_{0}+\alpha_{1} A G E+\alpha_{2} \text { FAMSIZE }+\alpha_{3} F E M P E R+\alpha_{4} C A S T E+\alpha_{5} E D U L V L+ \\
& \alpha_{6} O W N L A N D+\alpha_{7} S H G M E M+\alpha_{8} A E A R N+\alpha_{9} T R N G+\epsilon
\end{aligned}
$$

Here the dependent variable is $W O M E N E M P=$ Women Empowerment

Women empowerment has been measured using the empirical data collected in the village survey with six different variables:

- Become economically self-sufficient and control over her income

- Decision making power within the family in case of education, health, financial and household matters

- Consciousness about health and nutrition

- Freedom from domination / violence by the family member

- Political and legal awareness 
- Improvement in status within household and society

Based on the indicators of empowerment mentioned above women empowerment index have been constructed. In the above six cases, we have considered several questions on the basis of which women empowerment is measured. If we get 'Yes' response in 80 per cent cases we have assigned it as 'Yes' response which we coded as ' 1 ' and otherwise 'No' response and we coded it as ' 0 '. We have assessed each woman involved with the SHG separately. Based on the indicators of empowerment we have constructed Women Empowerment Index. All these six variables are a dichotomous variable where we coded 'Yes' response as ' 1 ' and a 'No' response as ' 0 '. To construct the women empowerment index, we have created a dummy variable that takes the value of ' 1 ' if at least four among all the six variables related to women empowerment have value ' 1 ' and otherwise have value ' 0 '. Thus, if the responses to at least four among all the six variables were 1 , the value of women empowerment index would be ' 1 '. If three of the variables were coded as ' 0 ', the value would be ' 0 '.

\section{Description of Explanatory Variables in Binary Probit Model}

$A G E=$ Age of Self-Help Group member in years

FAMSIZE = Family size i.e. the number of household members

FEMPER $=$ Percentage of female members in the household

$C A S T E=$ Caste of a woman is considered as categorical variable. $\mathrm{GEN}=1$, if a woman belongs to General Caste and 0 otherwise.

$E D U L V L=$ Formal education that a female SHG member gains through school, college and university etc. which is counted by the number of years of education

$O W N L A N D=$ Total land owned by the household in acre $\left(1\right.$ acre $\left.=4,047 \mathrm{~m}^{2}\right)$

SHGMEM = Duration of SHG membership, which is the period of time a woman remains a SHG member. It is counted by number of months

$A E A R N=$ Total monthly income of female SHG member measured in Indian Rupees

$T R N G=$ Training of female SHG member for productive enhancement in order to have increased income.

$T R N G=1$, if a femalemember has training which helps in enhancement of her productive skills and 0 otherwise.

Here $\alpha_{0}$ is constant and $\alpha_{i}(i=1,2, \ldots, 9)$ are the coefficients associated with the explanatory variables and $\in$ is the random disturbance term.

\section{EMPIRICAL RESULTS AND DISCUSSIONS}

Empowerment is about increased ability of the people to question, participate, negotiate, influence and control all aspects that affect their lives (Narayan, 2002). It is a process that involves greater control over one's resources and the ability to make decisions. Women Empowerment ensures women are not only able to express and defend their own rights but also have greater controlover it through enhanced confidence and self-esteem. The process of gaining control over one's selfand 
resources, which all are signs of gaining power can also be termed as empowerment. Women empowerment involves ensuring that the women are economically self-sufficient and self-reliant with increased self-esteem so as to confront any difficult situation in their lives.

\section{A. Social Impact of SHG Activities on the Respondents}

The Social impact of the various SHG activities carried out by the respondents during the Pre SHG stage and Post SHG stage in the study area have been tabulated in the Table 1.

Table 1: Social Impact of the respondents

\begin{tabular}{|c|c|c|c|c|c|c|c|c|c|}
\hline \multirow[b]{2}{*}{ SI No. } & \multirow[b]{2}{*}{$\begin{array}{l}\text { Social Impact on the SHG member } \\
\text { (High/Low) }\end{array}$} & \multicolumn{4}{|c|}{ Pandua Block } & \multicolumn{4}{|c|}{ Dhaniakhali Block } \\
\hline & & $\begin{array}{c}\text { Pre SHG } \\
\text { (nos. of } \\
\text { High) }\end{array}$ & $\begin{array}{c}\text { Percentage } \\
(\%)\end{array}$ & $\begin{array}{c}\text { Post SHG } \\
\text { (nos. of } \\
\text { High) }\end{array}$ & $\begin{array}{c}\text { Percentage } \\
(\%)\end{array}$ & $\begin{array}{c}\text { Pre SHG } \\
\text { (nos. of } \\
\text { High) }\end{array}$ & $\begin{array}{c}\text { Percentage } \\
(\%)\end{array}$ & $\begin{array}{c}\text { PostSHG } \\
\text { (nos.of } \\
\text { High) }\end{array}$ & $\begin{array}{c}\text { Percentage } \\
(\%)\end{array}$ \\
\hline 1 & Decision making power within the family & 35 & 17.50 & 127 & 63.50 & 12 & 12.00 & 43 & 43.00 \\
\hline 2 & Social Status and recognition & 38 & 19.00 & 97 & 48.50 & 24 & 24.00 & 32 & 32.00 \\
\hline 3 & Literacy (Able to read and sign) & 32 & 16.00 & 128 & 64.00 & 18 & 18.00 & 55 & 55.00 \\
\hline 4 & Better schooling of the children & 42 & 21.00 & 132 & 66.00 & 13 & 13.00 & 57 & 57.00 \\
\hline 5 & Selfindependence & 56 & 28.00 & 148 & 74.00 & 24 & 24.00 & 51 & 51.00 \\
\hline 6 & $\begin{array}{l}\text { Contacts with other Social workers within } \\
\text { the Block }\end{array}$ & 27 & 13.50 & 72 & 36.00 & 22 & 22.00 & 52 & 52.00 \\
\hline 7 & Participation in Political / Social activities & 25 & 12.50 & 86 & 43.00 & 17 & 17.00 & 55 & 55.00 \\
\hline 8 & Awareness of Government Schemes & 31 & 15.50 & 134 & 67.00 & 18 & 18.00 & 52 & 52.00 \\
\hline 9 & Domestic Violence & 143 & 71.50 & 86 & 43.00 & 86 & 86.00 & 22 & 22.00 \\
\hline
\end{tabular}

Source: Field Survey (2017-18)

From Table 1, we observe that the social life of the respondents has been greatly impacted after their participation in Self-Help Group. The percentage of decision-making power of the respondent within the family for Pre SHG stage and Post SHG stage was 17.50 per cent and 63.50 per cent respectively in Pandua Block and 12 per cent and 43 per cent respectively in Dhaniakhali Block. In the context of Social Status and recognition, we observe that after joining Self Help Group, there has been drastic improvement from 19 per cent to 48.50 per cent in Pandua Block. However, in Dhaniakhali Block the change from 24 per cent to 32 per cent is comparatively lower. From this data we can infer that the respondents have been socially active and have received recognition for their work after joining the Self-Help Group. The respondents have taken steps to increase their literacy level with respect to able to read and sign. The literacy per cent at Pre SHG-stage and Post SHG stage was 16 per cent and 64 per cent in Pandua Block and 18 per cent and 55 per cent in Dhaniakhali Block. After joining Self-Help Group, the respondents have ensured better schooling for their children with a rise from 21 per cent to 66 per cent in Pandua block and 13 per cent to 57 per cent in Dhaniakhali Block. Self-independency amongst the respondents has shown a positive trend with increase from 28 per cent to 74 per cent in Pandua Block and 24 per cent to 51 per cent in Dhaniakhali Block. After joining Self Help Group, the members have able to interact with each other effectively as indicated with the increase from 13.50 per cent to 36 per cent in Pandua Block and from 22 per cent to 52 per cent in Dhaniakhali Block, thereby increasing their interpersonal relationship. The participation of the members in various social activities like redressal of their family disputes, encouraging other family members to send their children to school, saving funds for education and marriage of their children, etc. have increased from 12.50 per cent to 43 per cent in Pandua 
Block and from 17 per cent to 55 per cent in Dhaniakhali Block. After joining Self Help Group, the awareness of various Government Developmental Schemes has risen from 15.50 per cent to 67 per cent in Pandua Block and from 18 per cent to 52 per cent in Dhaniakhali Block. On the context of domestic violence, more than half of the participants in both the blocks reported that it had decreased.

Ours being a patriarchy society, the men hold all the primary powers in the household and thus predominate in the participatory role of other household members in politics, society and control over the property. Women are normally not allowed to take any decision. From Table 1 we have observed that participation of women in Self-Help Groups have resulted in higher decision making and higher independence in a male dominated society. A few families, however, were reluctant to accept such social changes in the lives of the women.

\section{B. Sources of Income of the Members before and after being involved in SHG}

As income is one of the major points to be assessed in the study of women empowerment, activities of respondent were examined. Following Table 2 shows various activities before and after joining SHG in Pandua and Dhaniakhali Block.

Table 2:Economic Activities of the SHG members

\begin{tabular}{|l|r|r|r|r|r|r|r|r|}
\hline \multirow{2}{*}{\multicolumn{1}{c|}{ Activities }} & \multicolumn{4}{c|}{ Pandua Block } & \multicolumn{4}{c|}{ Dhaniakhali Block } \\
\cline { 2 - 10 } & \multicolumn{2}{|c|}{ Before joining SHG } & \multicolumn{2}{c|}{ After joining SHG } & \multicolumn{2}{c|}{ Before joining SHG } & After joining SHG \\
\cline { 2 - 10 } & Frequency & Percentage & Frequency & Percentage & Frequency & Percentage & Frequency & Percentage \\
\hline Agricultural labour & 37 & 18.5 & 41 & 20.5 & 28 & 28 & 28 & 28 \\
\hline Off farm Labour & 26 & 13 & 31 & 15.5 & 5 & 5 & 16 & 16 \\
\hline Casual work & 68 & 34 & 24 & 12 & 17 & 17 & 8 & 8 \\
\hline Small Business & 15 & 7.5 & 86 & 43 & 18 & 18 & 35 & 35 \\
\hline Homemaker & 54 & 27 & 18 & 9 & 32 & 32 & 13 & 13 \\
\hline Total & 200 & 100 & 200 & 100 & 100 & 100 & 100 & 100 \\
\hline
\end{tabular}

Source: Field Survey (2017-18)

From Table 2 above we observe that a large number of respondents in Pandua block were either engaged in casual labour (34 per cent) or were homemaker (27 per cent) before joining the SHG. After joining SHG in Pandua block there has been reduction in the number of members involved in casual labour (12 per cent) and being home maker ( 9 per cent) and an increase in small business (43 per cent). The same trend has also been observed in Dhaniakhali block where after joining SHG the per cent of the respondents involved in economic activities for casual labour changed from 17 per cent to 8 per cent; homemaker from 32 per cent to 13 per cent and small business from 18 per cent to 35 per cent. This empirical data justifies the fact that after joining SHG, there has been a positive influence on the members due to the increase in their income from their economic activities.

\section{Economic Impact of SHG Activities on the Respondents}

The economic impact of the respondents after joining Self Help Group in the Pandua and Dhaniakhali Block has been tabulated in Table 3 as shown below: 
Table 3: Economic impact of the respondents

\begin{tabular}{|c|c|c|c|c|c|c|c|c|c|}
\hline \multirow[b]{2}{*}{ SI No. } & \multirow[b]{2}{*}{ Level of Economic Impact on the SHG member } & \multicolumn{4}{|c|}{ Pandua Block } & \multicolumn{4}{|c|}{ Dhaniakhali Block } \\
\hline & & Pre SHG & $\begin{array}{c}\text { Percentage } \\
(\%)\end{array}$ & Post SHG & \begin{tabular}{|c} 
Percentage \\
$(\%)$
\end{tabular} & Pre SHG & $\begin{array}{c}\text { Percentage } \\
(\%)\end{array}$ & PostSHG & $\begin{array}{c}\text { Percentage } \\
(\%)\end{array}$ \\
\hline 1 & Access to the creditfacility & 19 & 9.50 & 166 & 83.00 & 11 & 11.00 & 68 & 68.00 \\
\hline 2 & Become Economically Selfsufficient & 27 & 13.50 & 107 & 53.50 & 16 & 16.00 & 41 & 41.00 \\
\hline 3 & Improved Nutrition In Household & 35 & 17.50 & 142 & 71.00 & 22 & 22.00 & 62 & 62.00 \\
\hline 4 & Family dependence to money lenders & 188 & 94.00 & 85 & 42.50 & 82 & 82.00 & 54 & 54.00 \\
\hline 5 & Save Money & 52 & 26.00 & 200 & 100.00 & 29 & 29.00 & 100 & 100.00 \\
\hline 6 & Create Asset & 33 & 16.50 & 129 & 64.50 & 14 & 14.00 & 44 & 44.00 \\
\hline
\end{tabular}

Source: Field Survey (2017-18)

From Table 3 above, we can observe that the access to better credit facility after joining Self-Help Group has drastically increased from 9.50 per cent to 83 per cent of the respondents in Pandua Block and from 11 per cent to 68 per cent respectively in Dhaniakhali Block. Post SHG, Economic Self-sufficiency amongst the members has shown an increase from 13.50 per cent to 53.50 per cent of the respondents in Pandua Block and from 16 per cent to 41 per cent respectively in Dhaniakhali Block. Joining Self Help Groups have ensured higher nutritional level in the household as evident from the Table with increase from 17.50 per cent to 71 per cent and from 22 per cent to 62 per cent of the respondent in Pandua Block and Dhaniakhali Block respectively. Family dependence on money lenders was also reduced from 94 per cent to 42.5 per cent in Pandua district and from 82 per cent to 54 per cent in Dhaniakhali Block after joining the Self-Help Group. There has been sharp increase in the monetary savings for all the members after joining Self-Help Group as there has been better control of their financial expenses thereby making them almost economically independent. Assets creation under various schemes of the microfinance has shown a forward trend after the members joined the group as evident from the Table 3 above from 16.50 per cent to 64.50 per cent of the respondents and from 14 per cent to 44 per cent for Pandua and Dhaniakhali blocks respectively.

\section{Regression Results and Discussions}

We have tested this regression equation using household level data collected through field survey in 6 villages of Pandua block and 4 villages of Dhaniakhali block in Hooghly District of West Bengal, India. We have estimated the regression equation by binary probit model using EViews economic software. The results of our analysis are presented in Table 4 . 
Table 4: Determinants of Women Empowerment (Pandua \& Dhaniakhali Block)

\begin{tabular}{|c|c|c|c|c|c|c|c|c|c|}
\hline \multicolumn{10}{|c|}{ Regression Result of Pandua and Dhaniakali Block } \\
\hline & \multicolumn{4}{|c|}{ Depended Variable: WOMENEMP } & & \multicolumn{4}{|c|}{ Depended Variable: WOMENEMP } \\
\hline & \multicolumn{4}{|c|}{ Method: Least Squares } & & \multicolumn{4}{|c|}{ Method: Least Squares } \\
\hline & \multicolumn{4}{|c|}{ Sample: 1200} & & \multicolumn{4}{|c|}{ Sample: 1100} \\
\hline & \multicolumn{4}{|c|}{ PANDUA BLOCK } & & \multicolumn{4}{|c|}{ DHANIAKHALI BLOCK } \\
\hline & Coefficient & Std. Error & z-Statistic & Prob. & & Coefficient & Std. Error & z-Statistic & Prob. \\
\hline Constant & -4.507042 & 1.642617 & $-2.743818^{*}$ & 0.0061 & Constant & -14.35259 & 7.578104 & $-1.893955^{* * *}$ & 0.0682 \\
\hline AGE & -0.045832 & 0.037734 & -1.214626 & 0.2245 & AGE & -0.053887 & 0.070464 & -0.764744 & 0.4444 \\
\hline FAMSIZE & -0.240068 & 0.312586 & -0.768006 & 0.4425 & FAMSIZE & -0.839517 & 0.65068 & -1.290214 & 0.1970 \\
\hline FEMPER & 0.052535 & 0.106031 & $0.495468^{*}$ & 0.0014 & FEMPER & 6.158306 & 5.279066 & 1.166552 & 0.2434 \\
\hline CASTE & 0.330910 & 0.347844 & 0.951317 & 0.3414 & CASTE & -1.779797 & 0.781369 & $-2.277794 * *$ & 0.0227 \\
\hline EDULVL & 1.608121 & 10.157830 & $0.158313 *$ & 0.0042 & EDULVL & 2.469313 & 1.221093 & $2.022215^{* *}$ & 0.0432 \\
\hline OWNLAND & -21.643560 & 74.776800 & -0.289442 & 0.7722 & OWNLAND & -7.227416 & 3.804095 & $-1.899904 * * *$ & 0.0674 \\
\hline SHGMEM & 0.005408 & 0.006543 & $0.826656^{* *}$ & 0.0184 & SHGMEM & 0.172643 & 0.081236 & $2.125209 * *$ & 0.0336 \\
\hline AEARN & 0.000014 & 0.000005 & $2.716821 *$ & 0.0066 & AEARN & 0.512504 & 0.440349 & 1.163858 & 0.2445 \\
\hline TRNG & 1.439463 & 0.512612 & $2.808095^{*}$ & 0.0050 & TRNG & 0.154203 & 0.814918 & $0.189225^{* *}$ & 0.0499 \\
\hline McFadden R-squared & 0.7327 & \multicolumn{2}{|c|}{ Mean dependent var } & 0.5250 & McFadden R-squared & 0.837125 & \multicolumn{2}{|c|}{ Mean dependent var } & 0.5200 \\
\hline S.D. dependent var & 0.5006 & \multicolumn{2}{|c|}{ S.E. of regression } & 0.2337 & S.D. dependent var & 0.502117 & \multicolumn{2}{|c|}{ S.E. of regression } & 0.2035 \\
\hline Akaike info criterion & 0.4699 & \multicolumn{2}{|c|}{ Sum squared resid } & 10.3729 & Akaike info criterion & 0.425533 & \multicolumn{2}{|c|}{ Sum squared resid } & 3.7285 \\
\hline Schwarz criterion & 0.6348 & \multicolumn{2}{|c|}{ Log likelihood } & -36.9876 & Schwarz criterion & 0.686050 & \multicolumn{2}{|c|}{ Log likelihood } & -11.2766 \\
\hline Hannan-Quinn criter & 0.5366 & \multicolumn{2}{|l|}{ Deviance } & 73.9753 & Hannan-Quinn criter & 0.530969 & \multicolumn{2}{|l|}{ Deviance } & 22.5533 \\
\hline Restr. Deviance & 276.7587 & \multicolumn{2}{|c|}{ Restr. Log likelihood } & -138.3793 & Restr. Deviance & 138.469400 & \multicolumn{2}{|c|}{ Restr. Log likelihood } & -69.2347 \\
\hline LR statistic & 202.7834 & \multicolumn{2}{|c|}{ Avg. Log likelihood } & -0.1849 & LR statistic & 115.916100 & \multicolumn{2}{|c|}{ Avg. Log likelihood } & -0.1128 \\
\hline Prob(LR statistic) & 0.0000 & & & & Prob(LR statistic) & 0.000000 & & & \\
\hline
\end{tabular}

*Significant at 1 per cent level, ** Significant at 5 per cent level, *** Significant at 10 per cent level

Source: Estimated by EViews computer software using field survey data of 2017-18

From the above Table 4, we observe that in most of the cases, the results are consistent with our hypothesis. As expected, Age ( $A G E$ ) has been found to have a negative influence on women empowerment in both Pandua and Dhaniakhali block in Hooghly District. This can be explained in the way that young and energetic female members are educated and their level of awareness towards economic, social and political empowerment is high compared to elder members. We hypothesized thatfamily size (FAMSIZE) was found to be negatively related to women empowerment. In our surveyed villages it is observed that a large family does not lead to a larger income for the household. Therefore, in our study area,as the family size increases the corresponding expenditure on food for the household also increases and thus leading to shortage of money for the household.This shortage in income is balanced through lower expenditure on education especially female education. Therefore, the female members do not get educational opportunity and they are mostly involved in household work. However, the result is not significant in both the blocks.

As expected, the coefficient of female per cent $(F E M P E R)$ is seen to be positive in both blocks. The Self-Help Group activities are primarily the involvement of the women. As the number of female members in the family increases relative to the male members, the importance of economic, social and political empowerment increases in the household. As female per cent increases in the family their involvement in decision making in family had been improved and they were treated with respect in their families. The female members would now protest against any bad treatment from other family members. However, the result is significant only in Pandua block. It is generally accepted norm that rural people belonging to General caste enjoy greater facilities from the SHGs as compared to people belonging to Schedule caste, Schedule Tribe or Other Backward caste. Therefore, it is hypothesized a positive relationship between caste and women 
empowerment. As expected, caste $(C A S T E)$ is positively related to women empowerment in Pandua block. However, in contrary to our hypothesis we observed negative and significant result in Dhaniakhali block. The educational level $(E D U L V L)$ was found to be one of the most important determinants of women empowerment. The results indicate a positive and significant relationship between education level and women empowerment in both the blocks. Education enables women to respond, challenge, control and change all aspects of theirlives. Education also helps the rural women households to have increased job opportunities and also look for alternate income sources. Hence educated people improve their status within and outside the family. In fact, educated female members understand the importance of economic, social and political empowerment. Hence with increase in female literacy the probability of women empowerment increases.

We hypothesized a positive relationship between women empowerment and land property $(O W N L A N D)$. Land property is seen as an important tool for increasing empowerment and economic welfare for women in India. In case a women member has ownership of land either singly or jointly, it results in increased bargaining power in the household towards decision making in the areas of own healthcare, mobility and asset creation. Land ownership empowers the women and also helps to provide income and security. However, we find contradictory result in this case in both Pandua and Dhaniakhali block and in Dhaniakhali block the result is significant. In our surveyed villages most of the respondents are very poor and they don't have much land property. In fact, high and middle-incomewomen are more benefited from these efforts, compared with the poor and uneducated women. The most important finding of this study is the impact of the Duration of Self-Help Group Membership (SHGMEM) on women empowerment and we hypothesized a positive relationship between the two. As expected, the results indicate that there is a positive and significant relationship between Duration of Self-Help Group Membership and women empowerment in both Pandua and Dhaniakhali block in Hooghly District. Self-Help Group membership leads to elevation in the social status of the women. They now have increased access to various Government or NGO schemes. The Self-Help Groupmembership ensures easy access to loans from the formal banks at an affordable rate in order to cater to their critical household expenses. With increased income there is marked improvement in the nutritional status of her family, education for her children and active participation indecision making in the family. After joining SHGs all the members have opened their savings accounts in the bank. They have been able to avail loan for investing in various small-scale income generating activities like dairy, retail shop, tailoring, etc. These investments have either been done individually by a SHG member or collectively by group of members. Few of the members utilised the money received from the bank as loan for repair of their houses. Few others also invested in purchase of gold jewellery with the notion that the prices of gold will appreciate over time. All these activities by the SHG members have ensured that their respect in the household has increased to a large extent. The women have also become economically self-sufficient and this has led to increased self-confidence, social and political awareness and mobility. Further, it is also observed that the incidence of violence against women members has also decreased to a great extent.

As expected, annual earnings $(A E A R N)$ has been found to have a positive impact on women empowerment in both Pandua and Dhaniakhali block. However, the result is significant only in Pandua block. This study establishes that higher levels of income of SHG beneficiaries has positively influenced the decision-making authority of women and has contributed significantly to empowerment of women. As they help in the family's financial assistance, they have become part of the family income. Before joining the SHG due to financial dependency, the women always had to consult their husband for taking any decisions related to purchase of essential household items, education of their children, healthcare, 
etc. However, after joining SHG the members have become financially independent and take decisions within the family towards purchase of essential household or personal items. The members have not only been able to take independent decisions but also oppose a decision taken by the family which was against the norms. The result is significant only in Pandua block.We observe that a positive relationship was found to exist between the training $(T R N G)$ received by the women and their empowerment. Training helps the members to learn new skills in different income generating activities. Training also ensures that the members are able to acquire knowledge about different technologies. This in turn leads to increase economic independence and upliftment of their livelihood resulting in increased women empowerment. The above results are significant in both the blocks of the study area.

\section{CONCLUSIONS}

Empowerment of Women is important for economic development of any country. In India, Self-Help Groups have a positive impact on the female members towards their empowerment. After joining SHG, there has been marked improvement towards relative freedom from dominance by the other family members and increased mobility. Due to higher mobility, the SHG members are now able to involve in various outdoor activities like taking their child to school, purchase of daily household items or visiting relatives without any hindrance from other family members. A major impact of SHG has been the members' ability to take decisions within the family. Members are now able to take decision towards children's education, purchase of any luxury household item, health care, etc. Economic enhancement of the SHG members has also ensured that they are able to contribute to the financial burden of the family by meeting small expenses towards children's education fee, medical expenses, daily household needs, etc. Self-Help Group members have become economically independent and secured as they have opened savings account in bank or post office. Their leadership quality improved as they also interacted with bank or post office officials on a regular basis. Self-Help Groups have helped their members in increased awareness of the current political and legal scenarios.

\section{POLICY PRESCRIPTIONS}

- The Government of India should take initiatives to solve the various problems and issues related to marketing of self-help group products

- In Panchayat areas, a cooperative society can be formed by the SHG members

- Non-Government Organizations (NGOs) have an important role to play towards women empowerment by ensuring that the SHG members are provided with the basic education, skill development and motivational training, and the required financial help for their economic betterment.

- Attractive insurance schemes can be provided to the Self-Help Group members

\section{REFERENCES}

1. Campbell Foundation, 2015, “Economic self-help group programs for improving women's empowerment: A systematic review", Volume 11, Issue 1, 2015, pp. 1-182

2. Dhiman, PAWAN KUMAR, and AMITA RANI. "A Study on Marketing Strategies of Self-Help Groups in Punjab: Challenges and Constraints. "International Journal of Sales \& Marketing Management Research and Development, 4 (3), 110 (2014).

3. Garai et al. (2012), "Empowerment of women through self-help group approach: Empirical evidence from west Bengal, India" African journal of agricultural research 7(48):.6395-6400, · December 2012 
4. Hashemi, S.M., S.R. Schuler, and Ann P. Riley (1996), "Rural Credit Programs and Women's Empowerment in Bangladesh," World Development, Vol. 2, No. 4 (1996): pp. 635-653.

5. Husain, et al. (2010), "Self Help Groups and empowerment of women: Self-selection or actual benefits? MPRA Paper No. 20765, posted $19 \mathrm{Feb} 201023: 36$ UTC

6. Kabeer, N (1999), "Resources, Agency, Achievements: Reflections on the Measurement of Women's Empowerment”, Volume 30, Issue 3, July 1999, pp. 435-464

7. KAMALA, SARAH, and UMA JYOTHI. "DYNAMICS AND PERFORMANCE OF WOMEN SELF HELP GROUPS IN TELANGANA STATE." International Journal of Educational Science and Research 8.3 (2018): 1-6.

8. Manvar H.A, Kathiriya, J.B, \& Thakar, D.S (2019), "Role of Self-Help Groups in Women Empowerment and Health", International Journal of Current Microbiology and Applied Sciences ISSN: 2319-7706 Volume 8 Number 04 (2019)

9. Mbugua-Muruthi, T (1997), "Strategies for survival in Kenya: women, education and Self-Help Groups", International Journal of Educational Reform, Volume 6, No.4 / October 1997

10. MURRY, NCHUMTHUNG, and R. NAKHRO. "PERCEPTION ON SOCIO ECONOMIC IMPACT OF SELF HELP GROUP PARTICIPATION BY TRIBAL WOMEN IN NAGALAND." International Journal of Educational Science and Research (IJESR) 9.6, Dec 2019, 11-16

11. Narayan, Deepa (ed). (2002), Empowerment and Poverty Reduction: A Sourcebook. Washington: World Bank

12. Randhawa, V. \& Mann, K.S. (2005), “Empowerment of Women Through Self Help Groups in Punjab”, Journal of Dairying, Foods \& H.S. 3(4). 178-183.

13. Sahu L, Singh Suresh K, (2012), "A qualitative study on role of help group in women empowerment in rural Pondicherry, India”, National Journal of informal region addition flexibility and continuity

14. Vasantha, S. "Challenges of self help group members towards income generation activity." International Journal of Accounting and Financial Management Research 4.2 (2014): 1-8.

15. World Economic Outlook, July, 2019, An update of Key WEO projections, International Monetary Fund, July 23, 2019 

